\title{
Characterisation of recycled ceramic mortars for use in prefabricated beam-filling pieces in structural floors
}

\author{
P. Rubio de Hita ${ }^{a}$, F. Pérez-Gálvez ${ }^{a}$, M.J. Morales-Conde ${ }^{b} \bowtie$, M.A. Pedreño-Rojas ${ }^{a}$ \\ a. Departamento de Construcciones Arquitectónicas 1, Escuela Técnica Superior de Arquitectura, \\ Universidad de Sevilla, (Sevilla, Spain) \\ b. Instituto Universitario de Arquitectura y Ciencias de la Construcción, Escuela Técnica Superior de Arquitectura, \\ Universidad de Sevilla, (Sevilla, Spain) \\ $\triangle$ mjesus.moralesconde@gmail.com
}

Received 30 April 2018 Accepted 27 November 2018 Available on line 20 March 2019

\begin{abstract}
This study analyses a procedure to manufacture mortars with different percentages of ceramic waste as partial replacement for aggregates. The study also examines the physical, chemical and mechanical properties of the new mortars, analysing substitution ratios that range from $10 \%$ to $50 \%$. Prior to this, all the materials used in the production of the mortar were characterised using X-ray diffraction (XRD) and fluorescence (XRF). The objective was to determine the similarity between different types of ceramic waste, as well as the differences in the minerology and chemical composition with the aggregate.

The results of the study show that it is possible to obtain mortars with lower densities compared to the same product with no recycled content. The product's characteristics make it ideal for the manufacture of prefabricated components for structural floors for rehabilitation works. Finally, the pieces are used in a real rehabilitation case study, highlightining the structural advantages.
\end{abstract}

KEYWORDS: Mortar; Ceramic; Mechanical properties; Modelization; X-ray Diffraction (XRD).

Citation/Citar como: Rubio de Hita, P.; Pérez-Gálvez, F.; Morales-Conde, M.J.; Pedreño-Rojas, M.A. (2019) Characterisation of recycled ceramic mortars for use in prefabricated beam-filling pieces in structural floors. Mater. Construcc. 69 [334], e189 https://doi.org/10.3989/mc.2019.04518

RESUMEN: Caracterización de morteros con cerámica reciclada y su uso en piezas prefabicadas para entrevigado de forjados. Este trabajo analiza morteros con diferentes porcentajes de cerámica reciclada como sustituto parcial de la arena. Además el estudio examina las propiedades físicas, químicas y mecánicas de los nuevos morteros, empleando diferentes porcentajes de sustitución $(10 \%-50 \%)$. Con anterioridad, se caracterizaron todos los materiales empleados en este trabajo mediante difracción y fluorescencia de rayos-X. El objetivo fue determinar las diferencias y similitudes en la composición química y mineralógica de los distintos tipos de residuos cerámicos y del resto de áridos utilizados.

Los resultados muestran que es posible obtener morteros con menor densidad frente a las muestras sin contenido reciclado. Sus características los hacen idóneos para la creación de piezas prefabricadas de entrevigado para rehabilitación de forjados. Finalmente. Las piezas se usaron en un caso de estudio real, destacando las ventajas estructurales que conlleva su uso.

PALABRAS CLAVE: Mortero; Cerámica; Propiedades Mecánicas; Modelización; Difracción de rayos X (DRX).

ORCID ID: P. Rubio de Hita (https://orcid.org/0000-0003-4473-9635); F. Pérez-Gálvez (https://orcid.org/00000002-1394-5113); M.J. Morales-Conde (https://orcid.org/0000-0002-7021-0914); M.A. Pedreño-Rojas (https://orcid. org/0000-0003-4622-8644)

Copyright: (C) 2019 CSIC. This is an open-access article distributed under the terms of the Creative Commons Attribution 4.0 International (CC BY 4.0) License. 


\section{INTRODUCTION}

Today in Spain, as in other European Union countries, waste valorisation is considered a priority, which has given rise to initiatives to minimize the impact of the waste that is most prevalent and hardest to recycle. According to the National Statistical Institute, in Mediterranean countries such as Spain the construction sector generated 32.7 million tonnes of waste material in 2011, which represents $51.17 \%$ of the nationwide total (1). Moreover, of all construction and demolition waste (CDW), ceramic materials accounted for $54 \%$ (2), partly from coating manufacturing (vertical and horizontal) and, to a lesser extent, from the production of bricks and roof tiles.

In addition, around $80 \%$ of ceramic CDW comes from building demolition, whereas $5-10 \%$ is material rejected because of defects or imperfections (3), offcuts or adjustments. The former are, therefore, materials with a high level of impurities, especially in the case of non-selective demolitions; and the latter are usually much more homogeneous and uniform, and which contain a significant amount of waste that can be reused, thus contributing to a reduction in the high rate of $\mathrm{CDW}$.

The common goal of reducing CDW has led researchers to undertake numerous studies on the potential for recycling building waste. In Spain, the National Waste Plan (PEMAR) (2016-2022) (4) aimed to promote the reuse of CDW, especially recycled aggregates, which yielded new products that complied with current regulations on construction, specifically in the case of recycled aggregate concrete. The feasibility of using this type of waste and its use in the manufacture of new products has impacted favourably on the environment, and this area has been a source of ongoing research in the last few years.

However, adding recycled aggregates to the manufacture of resistant products, such as structural concrete, comes with a reduction in their resistance properties, by limiting their compressive strength to $150 \mathrm{~kg} / \mathrm{cm}^{2}$. For this reason, the Spanish Regulation for Structural Concrete (EHE 2008) (5) restricts the use of recycled aggregate to $20 \%$ of the total aggregate, as well as limiting aggregate replacement to oversized particles due to the high water absorbing capacity of fine aggregate, because it diminishes the mechanical properties of the final product. Some studies in this field have examined recycled aggregate concrete as partial cement substitute to a level of $50 \%(6,7)$, as well as an aggregate substitute of up to $25 \%(8-12)$.

Research has tended to focus more on mortar, in which investigators have been able to manufacture products with good mechanical and physical properties for reuse in non-resistant structures, such as mortar for masonry. When so used, recycled materials were added as replacement for sand (13-16), for gravel as natural aggregate $(17,18)$ and for cement $(7,19-21)$, in several cases reaching a replacement ratio of $50 \%$.

Other studies have analysed mortar with recycled ceramic aggregate from production waste, in particular bathroom ceramic, producing mortars with excellent properties at a replacement rate of $25 \%$ of coarse aggregate $(8,10-12,18)$.

Most other articles in this field centre on the physical, mechanical and chemical properties of samples containing recycled material. However, few studies describe the practical application of recycled materials for construction purposes. Some refer to the use of mortars with recycled ceramic material for non-resistant products and elements such as concrete bricks and blocks $(22,23)$, pedestrian paving stones (22-25) or sub-base material for the construction of roads (26-28). In these papers, the waste used is mechanically shredded for later use in the manufacturing of the cement, as a replacement for the cement itself, in order to obtain mortars or additives.

The research in this paper aims to take ceramic waste, discarded as defective, as offcuts or surplus to requirements, and add it to the manufacturing process for new mortars to substitute natural aggregate. The objective is to achieve the maximum possible percentage of waste content that allows to obtain a mortar with adequate physical and mechanical properties for developing a beamfilling piece for wooden structural floors. The aims is for these infill blocks to be used in rehabilitation processes, in order to recover the traditional structural and construction systems applied to historic buildings. This will also contribute to construction sector sustainability, with the use of waste materials, and to the recovery of traditional construction systems.

\section{EXPERIMENTAL PROCEDURE}

This study is divided into different stages:

- Phase 1: Identification and characterization of the materials used. The raw materials and products from industrial ceramic waste to be recycled, and which contain no cracks or firing defects, are characterized.

- Phase 2: Crushing of ceramic waste and selection of the appropriate grading size following sieving.

- Phase 3: Development of test pieces at different percentages $(10,20,30,40,50 \%)$, for substituting aggregates with recycled ceramics.

- Phase 4: Characterization of the mortar produced, determining its physical-mechanical properties and identifying the mineralogical phases in the mortars. This characterisation will yield 
the best mortar for the manufacture of infill blocks.

- Phase 5: Development and testing of infill made of the most suitable mortar. Verification of compliance for use in building works.

\subsection{Characterisation of the materials}

The following materials were used in the manufacture of the mortar (Figure 1):

- B1/A-L 42.5R Portland cement, to Spanish RC-16 Cement Receipt Instruction (RC-16) standards (29).

- A commercial sand with a maximum grain size of $8 \mathrm{~mm}$ (TMA $8 \mathrm{~mm}$ ) was used as natural aggregate.

- Ceramic aggregate from leftover unglazed ceramic flooring measuring $14 \times 28 \mathrm{~cm}$, which was crushed to a size of $10-12.5 \mathrm{~mm}$ before use. After milling, the aggregate was sieved and classified into the following particle sizes, in compliance with the UNE-EN 933-1 standard (30):
$10,8,4,2,1,0.5,0.25,0.125 \mathrm{~mm}$. Aggregates with a particle size smaller than 0.063 were not included. Finally, the aggregates were dried in a stove at $110 \pm 5^{\circ} \mathrm{C}(30)$ to constant weight.

No additives were used in the mix.

To determine the main elements in the materials, a mineralogical analysis was conducted by X-ray diffraction (XRD), using PANALYTICAL-Axios equipment (with rhodium excited at 4kW); an X-ray diffractometer with a BRUKER-D8 Advance A25 (DI81I-90) was also used, as well as a $\mathrm{Cu}$ anode excited at $40 \mathrm{kV}$ and $30 \mathrm{~mA}$. In this way, the crystalline phases of the different materials were obtained (cement, natural aggregate and ceramic aggregate), and the natural aggregates were compared to the ceramic content. In order to study the similarity between the different elements of ceramic production two types of ceramic waste were compared: unglazed ceramic tiles and simple hollow ceramic brick.

Quantitative data obtained with X-Ray fluorescence spectroscopy (Table 1) revealed that both the
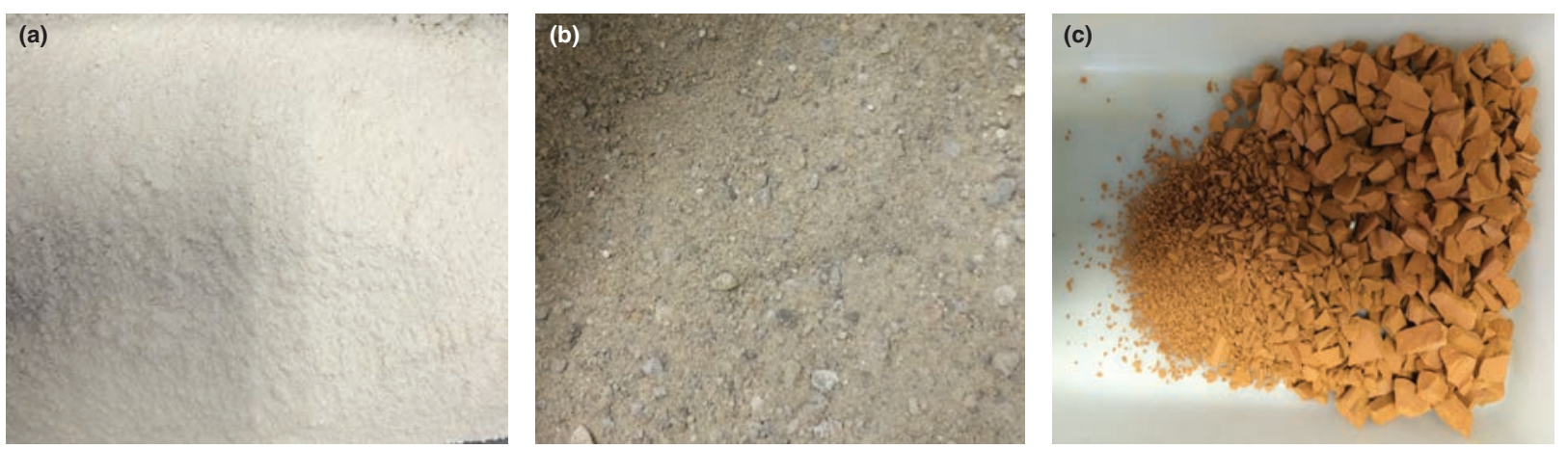

FIGURE 1. Materials before processing: Portland cement, natural aggregate, ceramic waste.

TABLE 1. Quantification of the main elements in the material samples.

\begin{tabular}{|c|c|c|c|c|}
\hline Chemical Constituent & $\begin{array}{l}\text { Portland cement } \\
(w t \%)\end{array}$ & $\begin{array}{c}\text { Sand aggregate } \\
(\mathbf{w t} \%)\end{array}$ & $\begin{array}{c}\text { Ceramic aggregate } \\
(\mathbf{w t} \%)\end{array}$ & $\begin{array}{c}\text { Ceramic brick } \\
(w \mathrm{wt} \%)\end{array}$ \\
\hline $\mathrm{SiO}_{2}$ & 18.75 & 77.5 & 54.17 & 62.13 \\
\hline $\mathrm{Al}_{2} \mathrm{O}_{3}$ & 2.93 & 6.41 & 17.20 & 13.35 \\
\hline $\mathrm{Fe}_{2} \mathrm{O}_{3}$ & 0.13 & 2.22 & 6.91 & 5.14 \\
\hline $\mathrm{MnO}$ & 0.00 & 0.05 & 0.08 & 0.05 \\
\hline $\mathrm{MgO}$ & 0.34 & 0.50 & 5.24 & 2.28 \\
\hline $\mathrm{CaO}$ & 64.99 & 3.73 & 6.70 & 8.18 \\
\hline $\mathrm{Na}_{2} \mathrm{O}$ & 0.04 & 1.22 & 0.35 & 0.51 \\
\hline $\mathrm{K}_{2} \mathrm{O}$ & 0.32 & 1.71 & 4.78 & 3.64 \\
\hline $\mathrm{TiO}_{2}$ & 0.07 & 0.26 & 0.76 & 0.75 \\
\hline $\mathrm{P}_{2} \mathrm{O}_{5}$ & 0.02 & 0.05 & 0.15 & 0.13 \\
\hline $\mathrm{SO}_{3}$ & 2.65 & 0.03 & 1.14 & 1.78 \\
\hline Other elements & 9.02 & 4.13 & 3.11 & 2.14 \\
\hline TOTAL & 99.26 & 97.81 & 100.58 & 100.07 \\
\hline
\end{tabular}


commercial aggregate and the ceramic waste have silica as their main component, and in similar proportions. Furthermore, it can be observed that the composition of the remaining elements is similar in the commercial aggregate and in both ceramic materials, so the substitution of part of the natural aggregate with recycled content would seem to be appropriate for the manufacture of the mortar.

Results from the XRD are presented in Table 2. All the crystalline phases of the ceramic waste are very similar to each other in the case of bricks and unglazed ceramic tiles. This implies that ceramic bricklaying waste could be used in both new construction and rehabilitation, along with discarded material from industrial ceramic production.

\subsection{Mortar production. Preparation of test pieces}

Ceramic waste mortars were produced at different ratios: 10, 20, 30, 40 and 50\% (PC10, PC20, PC30, PC40, PC50). A reference mortar made from commercial aggregate and with no additional waste content (PC) was also manufactured for use as a sample to compare the results obtained in each case.
The procedure for mortar production includes the following stages:

- Determination of commercial aggregate granularity by sieving in accordance with UNE-EN 933 standard (30).

- Selection of ceramic waste granules through sieving (30): the ceramic material was classified according to particle size for later use in the mortar mass.

- Determination of the necessary quantities of the ceramic waste particle fraction in relation to substitution ratios for each sample, replacing commercial aggregate with ceramic waste. In this way, an identical grading size (commercial and recycled) was adopted for all samples, regardless of the proportions recycled. In the overlay of the two grading curves (commercial and recycled aggregate), it can be observed how similar they are to one another (Figure 2).

- Ceramic waste moistening. The recycled aggregate will be enveloped by a wet layer during the phase when it is added to the mix. This layer is formed by immersion of the aggregate before mixing with the rest of the mortar components.

- Mixing commercial aggregate and ceramic waste with cement, replacing different percentages of

TABLE 2. Crystalline phases and Rietveld parameters.

\begin{tabular}{|c|c|c|c|c|}
\hline Mineral composition & $\begin{array}{l}\text { Portland cement } \\
\text { (Sample 1) }\end{array}$ & $\begin{array}{c}\text { Sand } \\
\text { (Sample 2) }\end{array}$ & $\begin{array}{l}\text { Crushed ceramic } \\
\text { (Sample 3) }\end{array}$ & $\begin{array}{l}\text { Ceramic brick } \\
\text { (Sample 4) }\end{array}$ \\
\hline Albite (feldspar) & & 11.30 & 16.70 & 17.20 \\
\hline Anatase & & & 0.60 & 1.00 \\
\hline Amphibole & & 1.10 & & \\
\hline Anhydrite & 0.40 & & & \\
\hline Biotite (mica) & & 1.30 & & \\
\hline C2s (dicacticsilicate) & 20.70 & & & \\
\hline $\begin{array}{l}\text { C3a (tricaccal } \\
\text { aluminate) }\end{array}$ & 1.00 & & & \\
\hline C3s (tricactericsilicate) & 49.70 & & & \\
\hline Calcite & 24.50 & 6.00 & 6.80 & 4.80 \\
\hline Kaolinite & & 2.20 & & \\
\hline Corundum & & & 0.20 & \\
\hline Quartz & & 67.00 & 16.60 & 35.70 \\
\hline Dolomite & 1.80 & & & \\
\hline Enstantite (pyroxene) & & & 11.50 & 3.40 \\
\hline Fayalite & & & 7.70 & 0.80 \\
\hline Hematite & & & 4.00 & 3.70 \\
\hline Microline (Feldspar) & & 3.00 & 15.10 & 20.20 \\
\hline Muscovite & & & 17.30 & 9.60 \\
\hline Orthoclase (Feldspar) & & 6.40 & & \\
\hline Phyllosilicates & & 2.10 & & \\
\hline Plaster & 1.40 & & 3.60 & 3.60 \\
\hline
\end{tabular}




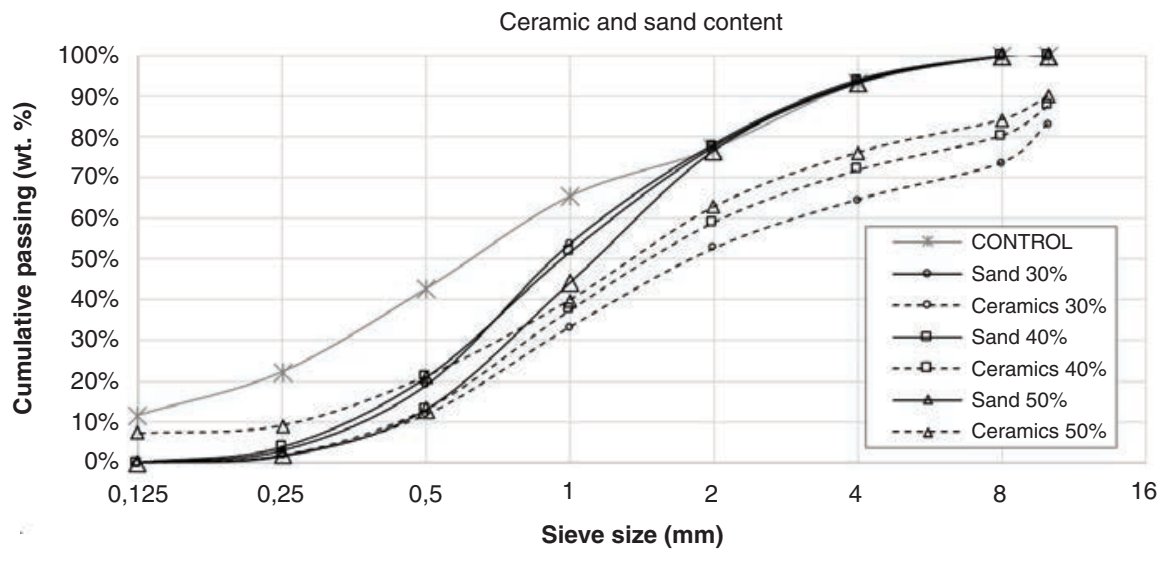

Figure 2. Ceramic aggregate size grading curves (PC, P30, P40, P50)

TABLE 3. Mortar mixing proportions.

\begin{tabular}{|c|c|c|c|c|c|c|}
\hline \multirow[b]{2}{*}{ Mix } & \multicolumn{4}{|c|}{ Materials $\left(\mathrm{kg} / \mathrm{m}^{3}\right)$} & \multicolumn{2}{|c|}{ Ratios } \\
\hline & $\begin{array}{l}\text { Natural aggregate } \\
\text { (NA) }\end{array}$ & $\begin{array}{l}\text { Ceramic waste } \\
\text { (CW) }\end{array}$ & $\begin{array}{l}\text { Cement } \\
\text { (C) }\end{array}$ & $\begin{array}{l}\text { Water } \\
\text { (W) }\end{array}$ & $\mathrm{Cl}(\mathrm{CW}+\mathrm{NA})$ & W/C \\
\hline$\overline{\mathrm{PC}}$ & 1529.69 & 0.00 & 254.95 & 229.45 & $1 / 6$ & 0,90 \\
\hline PC10 & 1415.25 & 157.25 & 262.08 & 235.87 & $1 / 6$ & 0.90 \\
\hline $\mathrm{PC} 20$ & 1215.47 & 303.87 & 253.22 & 227.90 & $1 / 6$ & 0.90 \\
\hline PC30 & 1008.42 & 442.47 & 240.10 & 228.10 & $1 / 6$ & 0.95 \\
\hline PC40 & 860.52 & 573.68 & 239.03 & 239.03 & $1 / 6$ & 1.00 \\
\hline PC50 & 689.61 & 689.61 & 229.87 & 241.36 & $1 / 6$ & 1.05 \\
\hline
\end{tabular}

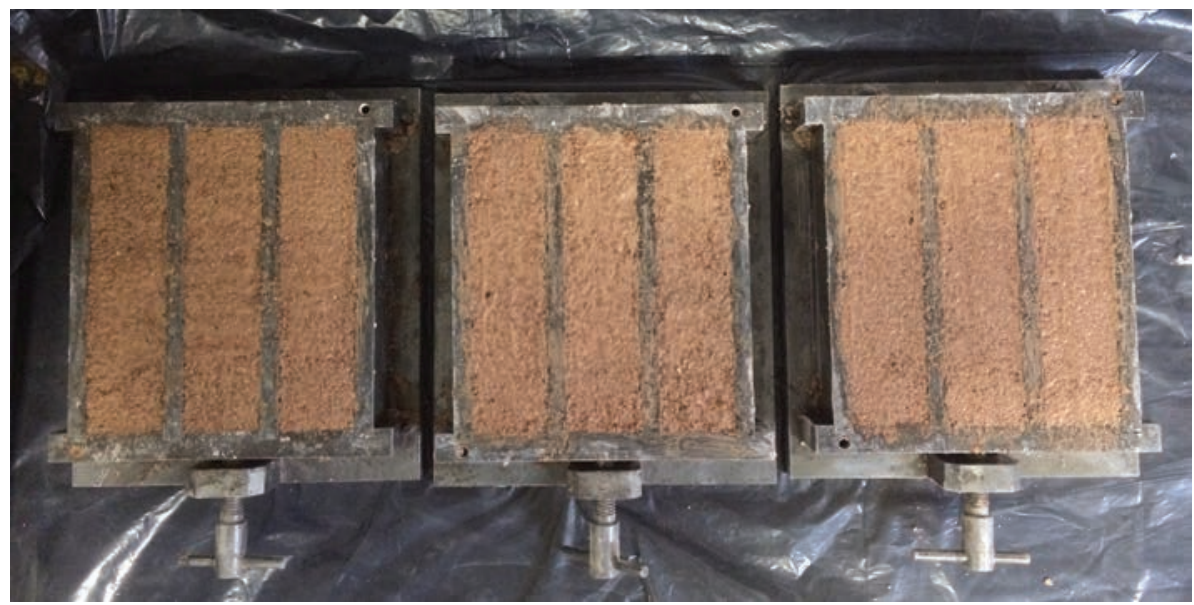

FIgURE 3. Manufacture of mortar specimens with $40 \%$ ceramic waste.

commercial aggregate with the same amount of ceramic material.

- Adding water in proportions ranging from 0.90 to 1.05 with regard to the cement weight ratio. These proportions vary depending on the percentage of recycled ceramic added to the mortar.

In Table 3, the amounts and proportions of each material are represented for the different mixes analysed. It can be observed that the cement-to-aggregate (natural and recycled) ratio is always the same. However, the water-to-cement ratio varies in accordance with the percentage of recycled ceramic used, rising as the recycled aggregate content increases, in order to ensure the workability of the mortar.

For each mixture, 18 prismatic test pieces of $40 \times 40 \times 160 \mathrm{~mm}^{3}$ were produced and later evaluated (Figure 3). When ready, the test samples underwent a curing process at $20 \pm 2^{\circ} \mathrm{C}$ for 28 days. During this period, relative humidity was maintained at $95 \pm 5 \%$ 
for the first 7 days, and at $65 \pm 5 \%$ for the remaining 21 days, according to the UNE-EN 1015-11 standard (31). After curing, the pieces were analysed, as established in the test plan (Table 4).

\subsection{Mortar characterisation tests}

In order to characterise the mortars, the following tests were conducted, according to regulatory procedures (Table 4). Mineralogical tests were also carried out on two samples, PC and PC-30, using XRF and XRD, to study how the addition of ceramic aggregate affected the chemical composition of the mortars and the formation of the crystalline phases.

\section{RESULTS AND DISCUSSION}

\subsection{The consistency-density relation of fresh mortars}

Figure 4 shows the effect of adding recycled ceramic with regard to the workability of the mixture. The higher the percentage of recycled ceramic in the mortar, the greater the amount of water needed in order to guarantee adequate consistency.

The fresh density tests (32) (Figure 5) yielded mortars with a density higher than $1200 \mathrm{Kg} / \mathrm{m}^{3}$, and since no fluidiser additive was used, the consistency value should be between 165 and $185 \mathrm{~mm}$ (33). This explains the need to change the water ratio in mixtures with the highest percentage of recycled ceramic.

\subsection{Density of hardened mortar}

Figure 6 shows the average bulk density values for hardened mortars at 28 days (34). It is observed that density decreases as the percentage of recycled ceramic rises, reaching values close to $1850 \mathrm{Kg} / \mathrm{m}^{3}$ for mortars with $50 \%$ recycled content, which entails a reduction of $7.89 \%$ compared to the reference mortar. The decrease in the mortars' density benefits the manufacture of prefabricated pieces because a reduction in the net weight of the elements, in this case structural floors, is achieved, which makes it suitable for rehabilitation works.

TABLE 4. Methods for characterizing the mortar

\begin{tabular}{|c|c|c|}
\hline & Characteristic & $\begin{array}{c}\text { Standard test } \\
\text { method }\end{array}$ \\
\hline \multirow{6}{*}{ 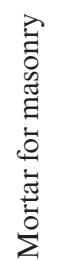 } & Determination of particle size distribution (by sieve analysis) & UNE EN 933-1 (30) \\
\hline & Determination of consistency of fresh mortar (by flowable) & UNE EN 1015-3 (33) \\
\hline & Determination of bulk density of fresh mortar & UNE EN 1015-6 (32) \\
\hline & Determination of dry bulk density of hardened mortar & UNE EN1015-10 (34) \\
\hline & Determination of flexural and compressive strength of hardened mortar & UNE EN 1015-11 (31) \\
\hline & Determination of water absorption coefficient (capillary action of hardened mortar) & UNE EN 1015-18 (35) \\
\hline \multicolumn{2}{|r|}{ Concrete tests. Determination of the modulus of elasticity in compression } & UNE EN 12390-13 (36) \\
\hline
\end{tabular}

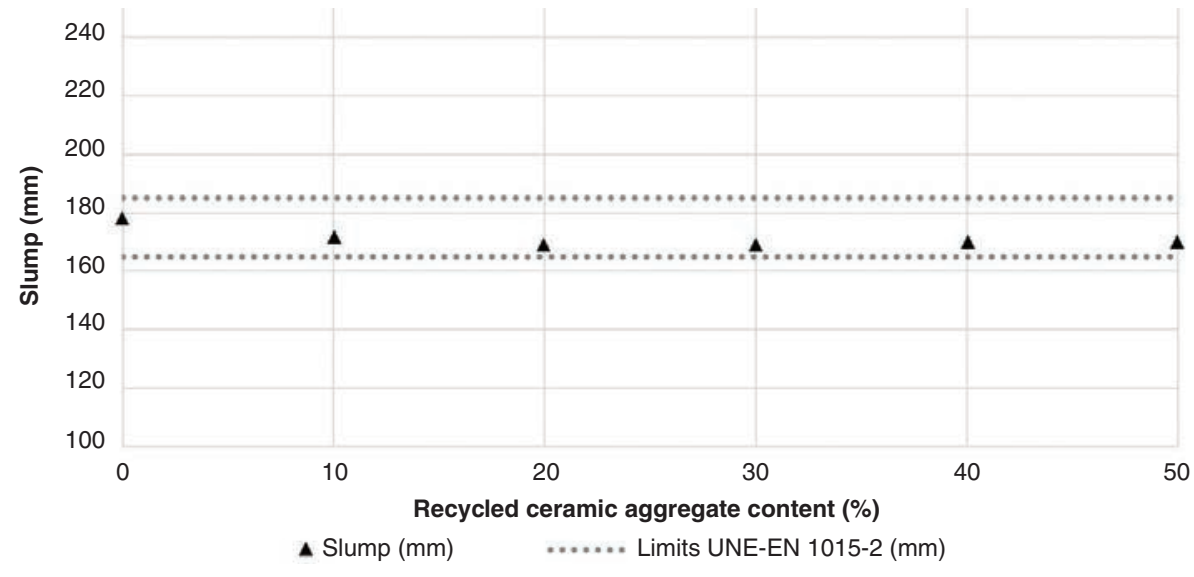

Figure 4. Consistency of fresh mortar 


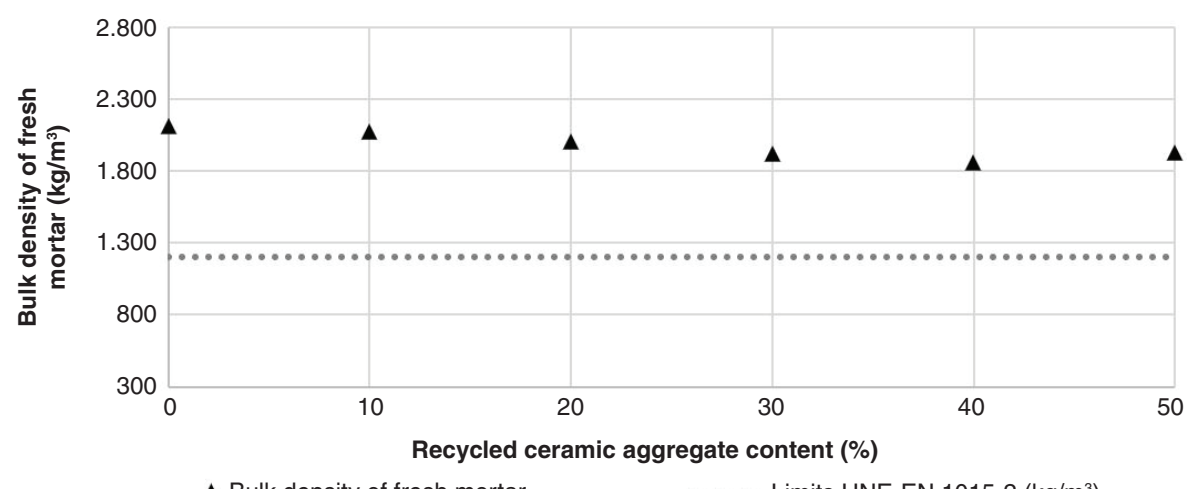

$\Delta$ Bulk density of fresh mortar

•... Limits UNE-EN 1015-2 $\left(\mathrm{kg} / \mathrm{m}^{3}\right)$

FIGURE 5. Relation of the average bulk density of fresh mortar to ceramic content.

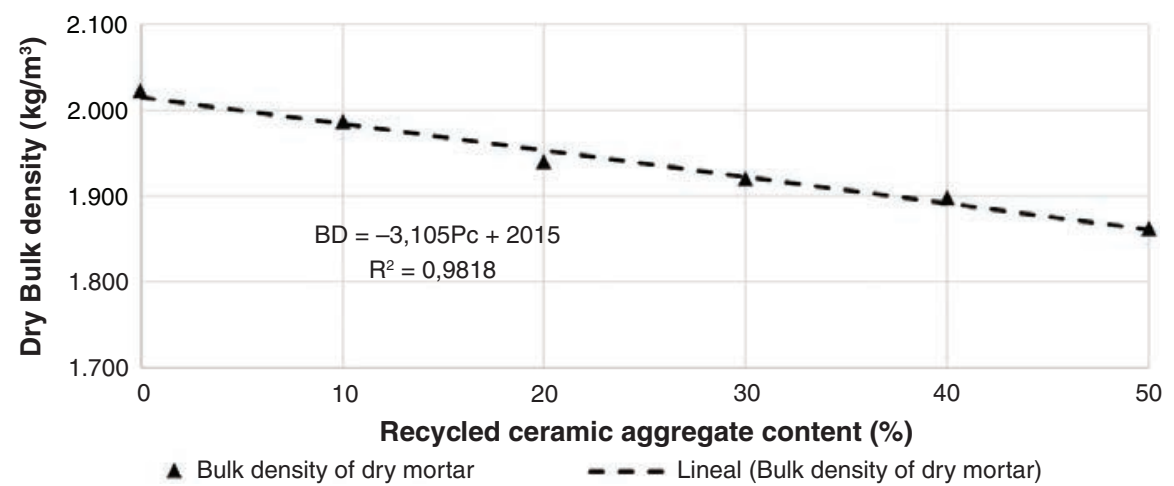

FIGURE 6. Relation of the average bulk density of dry mortar to ceramic content.

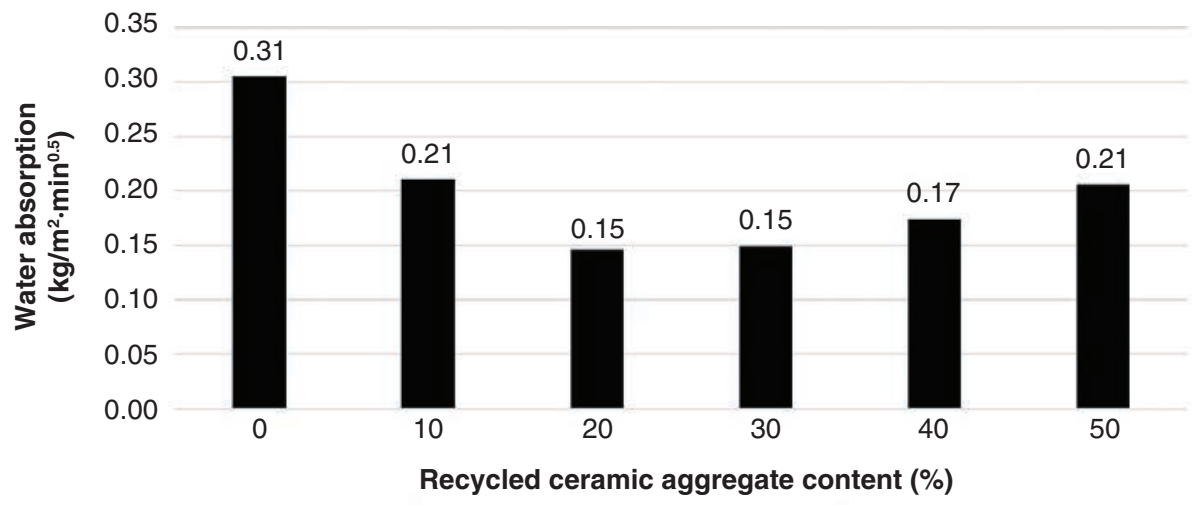

FIGURE 7. Effect of the content of ceramic waste on physical properties. Water absorption

\subsection{Capillary water absorption}

Capillarity water absorption (35) (Figure7) decreases considerably in test pieces PC-20 and PC-30 in contrast to the reference mortar, while it clearly increases in mixtures with a high percentage of ceramic content. The ceramic material's absorption capability is a crucial factor in the choice of the best mortar for the manufacture of pieces, as well as its porosity values and mechanical resistance.

\subsection{Porosity}

Computed tomographies were conducted on all the test piece series to determine their morphology and to gather information on their porosity (Figure 8, Figure 9). The tomography equipment used was the YXLON Cougart model, which produced 2D images that showed the ceramic distribution within the mixtures as well as the proportion of pores, which increases as the amount 

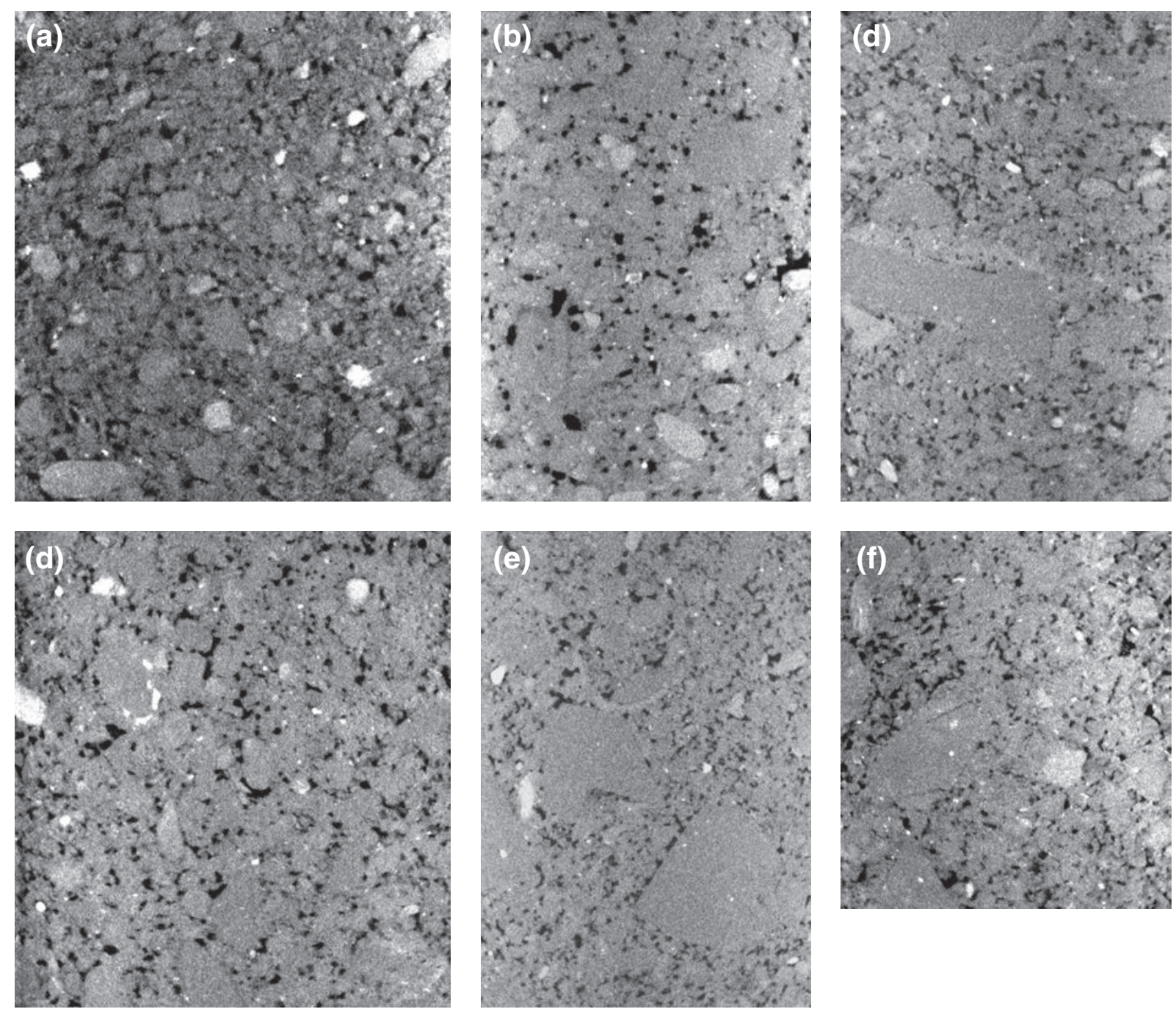

FIgure 8. 2D pictures from the CT scan (a. PC, b. PC-10, c. PC-20, d. PC-30, e. PC-40, f. PC-50)

of ceramic material rises, leading to a less homogeneous distribution.

The quantitative study of the porosity reveals a progressive rise in this parameter when the percentage of ceramic aggregate increases. This trend holds for mortars with up to a $50 \%$ substitution ratio (Figure 10). In test pieces PC-40 and PC-50 linear progression is maintained in relation to the ratio of pores, with a different distribution in mixtures with low ceramic content, generating areas of pore concentration around the ceramic aggregate and, consequently, a less homogeneous distribution.

\subsection{Mechanical behaviour. Flexural and compressive strength}

Figure 11-12 show data obtained in flexural and compressive strength tests (31), which were determined for all the mixtures at 7 and 28 days.
It can be observed that flexural strength increases up to a recycled ceramic ratio of $30 \%$ (PC-30) compared to the reference mortar. However, in test pieces with a higher proportion of recycled ceramic, flexural strength decreases due to the increase in the amount of water used in the mixing process, as well as to the aggregate distribution in the mixtures, which is less homogeneous and has increased porosity.

Compression strength considerably increases in the mixtures with a proportion of 20 and $30 \%$ (PC20, PC-30), in relation to the reference test piece (PC) (Figure 12). From that percentage onwards, no improvements in mechanical strength are achieved.

The results for mechanical resistance provide data that is very useful when selecting the best mortar for manufacturing prefabricated pieces in horizontal structures, the mortar with $30 \%$ recycled ceramic being the most appropriate for this purpose. 

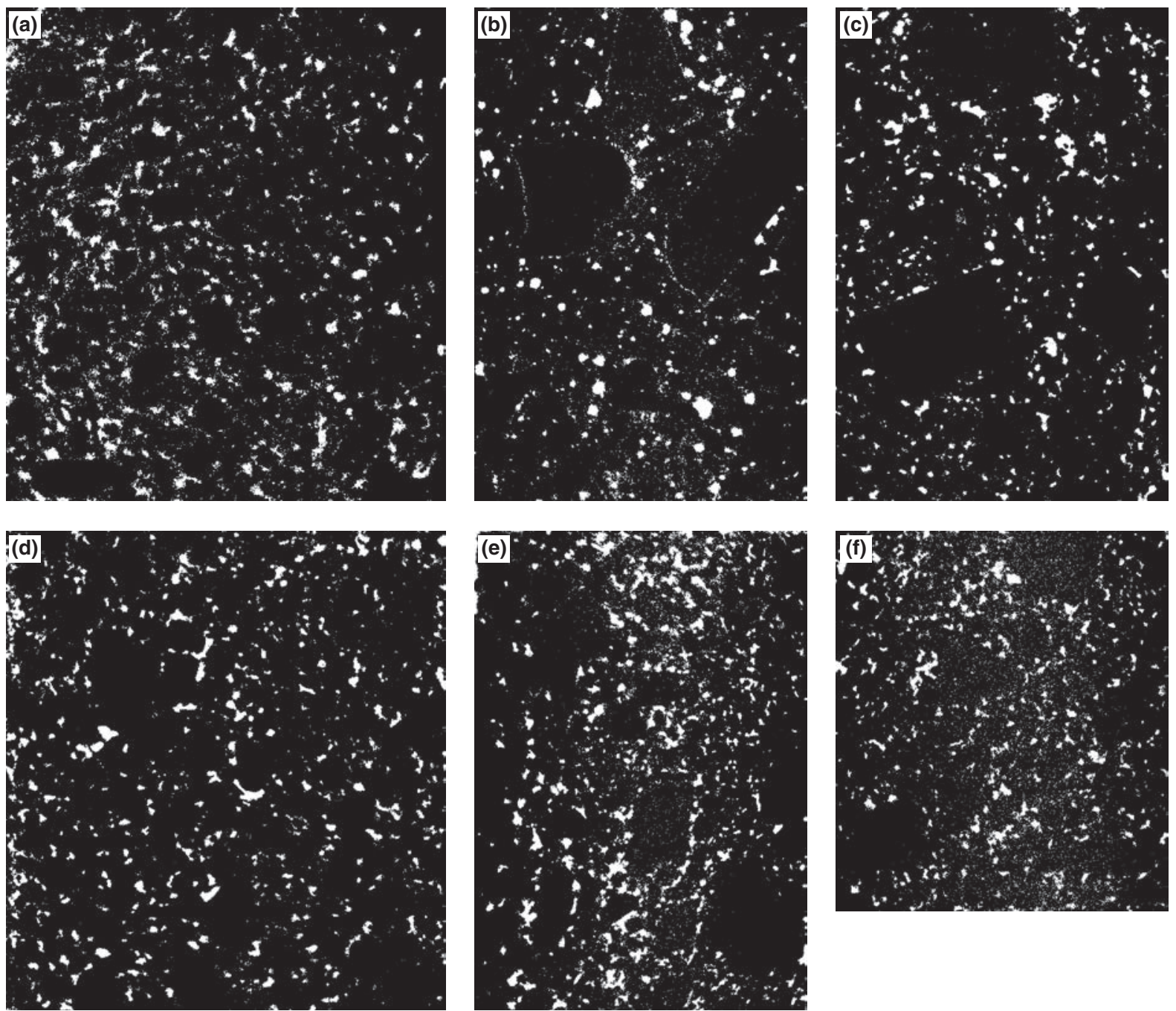

Figure 9. Bump pictures to obtain pore networks from the samples collected (a. PC, b. PC-10, c. PC-20, d. PC-30, e. PC-40, f. PC-50)

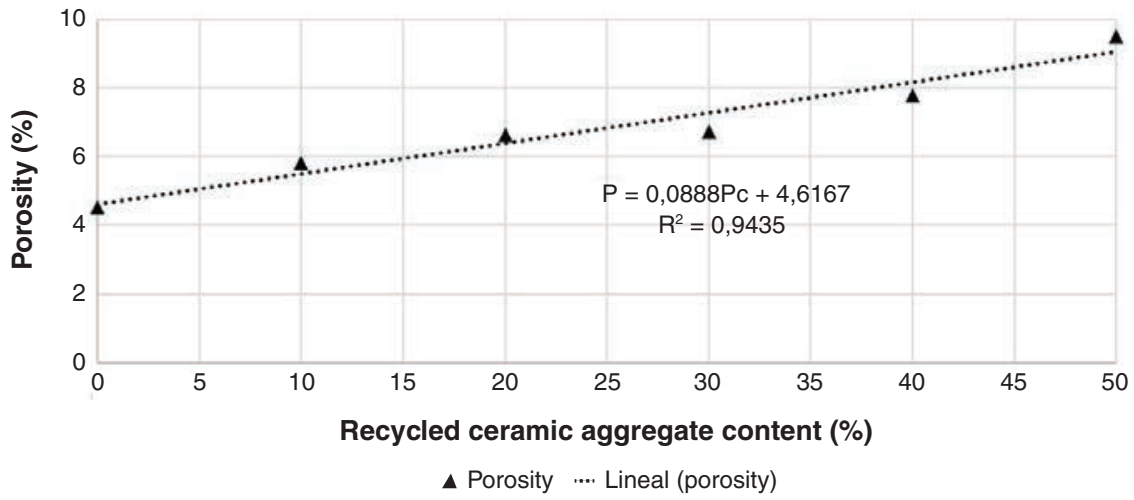

FIGURE 10. Porosity according to total CT statistical analysis

Mechanical resistance development during the curing process provides information on how the ceramic content influences the setting process and the endurance of the mortars. In the case of mortars with a maximum $30 \%$ recycled ceramic, compressive strength at 7 days amounts to around $60-70 \%$ of the resistance values obtained at 28 days. Therefore, ceramic as a substitute for aggregate does not affect the development of resistant qualities over time for mortars with these percentages. Above this amount 


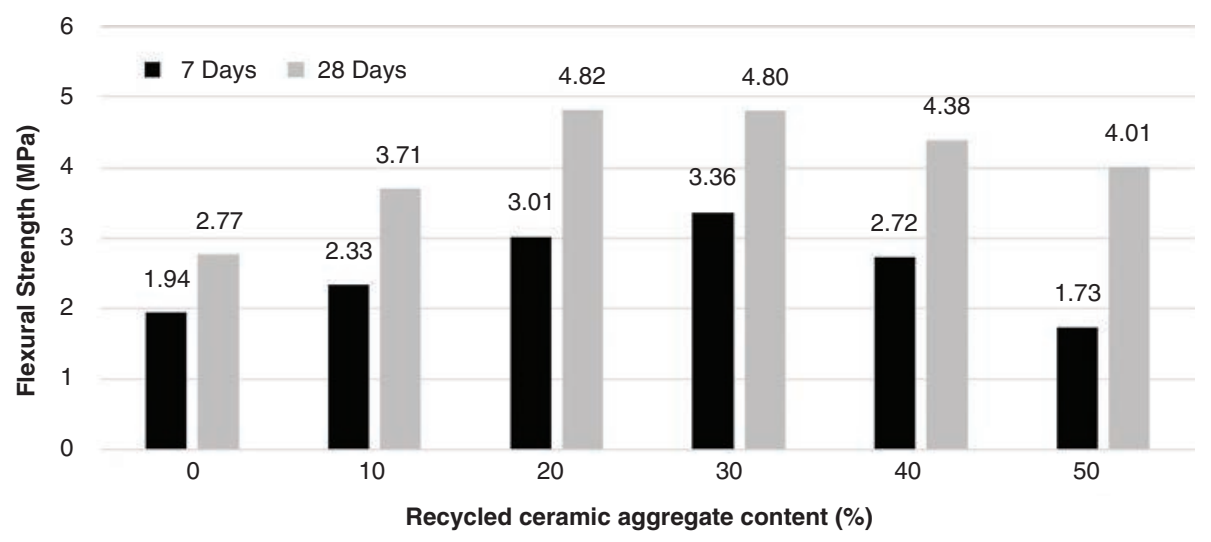

Figure 11. Flexural Strength

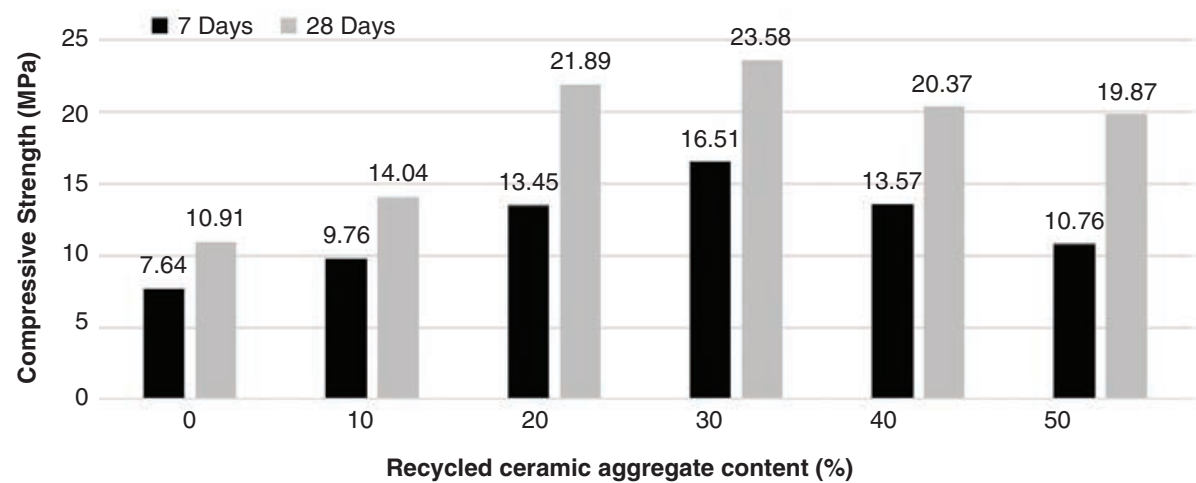

FIgure 12. Compressive Strength

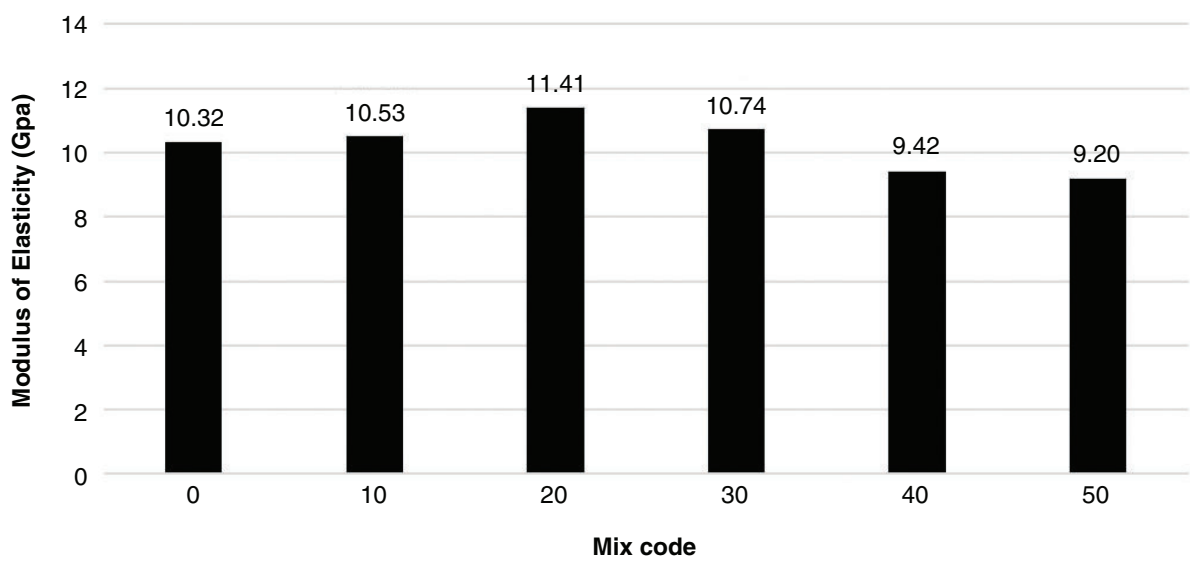

FIGURE 13. Modulus of elasticity of mixtures (28 days)

of recycled additives, progress evolves in a different way especially in mixtures with $50 \%$ ceramic (Figure 11 and 12).

\subsection{Modulus of elasticity}

The modulus of elasticity is determined by flexural rupture testing based on the stress-strain graphics (36). An increase in this parameter was observed in mortars with recycled ceramic additives up to $20 \%$ (PC-20) (Figure 13). This indicates greater compactness in the mortars and improvements in their mechanical properties. Nevertheless, mixtures with a high-recycled ceramic ratio $(40-50 \%)$ experience a reduction in the modulus of elasticity, resulting in a less compact and homogeneous mortar since it is affected by an increase in the mixing water and a heterogeneous ceramic distribution within the pieces (Figure 14). 

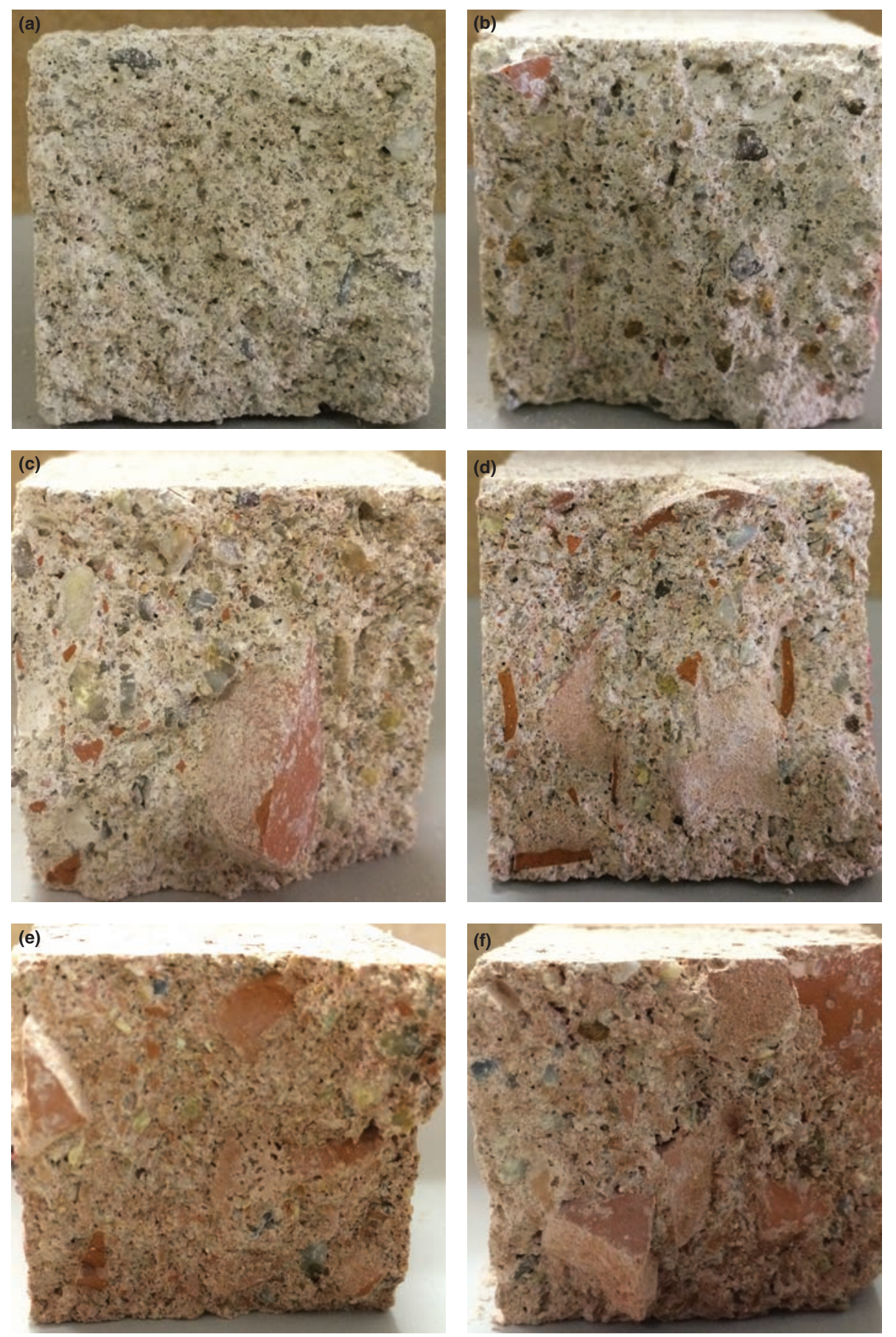

FIgure 14. Cross-section of test specimens (a. PC, b. PC-10, c. PC-20, d. PC-30, e. PC-40, f. PC-50)

\section{DEVELOPMENT OF A CONSTRUCTION APPLICATION: AN INFILL MADE OF MORTAR WITH CERAMIC WASTE}

The experimental study conducted has allowed us to characterise mortars with different proportions of recycled ceramics, with the conclusion that the addition of ceramic at a ratio of $30 \%$ produces a lighter material with better physical and mechanical properties than traditional mortar. Subsequently, an infill, or joist-to-joist fill, was produced using this mortar, for use mainly in the rehabilitation of traditional structural floors with brick jack arch slabs and wood beams (Figure 15), as well as to recover 
traditional typologies. The production of this new piece can help resolve the problem entailed in rehabilitating buildings with wood structural floors, typical of $17^{\text {th }}-$ to- $19^{\text {th }}$ century constructions, by replacing the original infill blocks with the recycled solution proposed.

\subsection{Description of the piece}

The infill, or joist-to-joist fill, has the following technical characteristics (Figure 16) (37):

- The piece can easily bridge the gap between joists ranging from 19 to $38 \mathrm{~cm}$ (a) with a tolerance of $\pm 5 \%$.

- The width of the piece is established at $25 \mathrm{~cm}$ (b) with a tolerance of $\pm 5 \%$

- The cant height of the piece can range from $8 \mathrm{~cm}$, for pieces with a smaller gap between joists, to $16 \mathrm{~cm}$, for higher inter-joist frameworks (e).

- The key thickness is a minimum of $3 \mathrm{~cm}$ (f) with a tolerance of $\pm 1 \%$.

- The total height of the piece depends on the dimensions of the wood beams upon which it rests, between 10.5 and $18.5(\mathrm{~g})$.

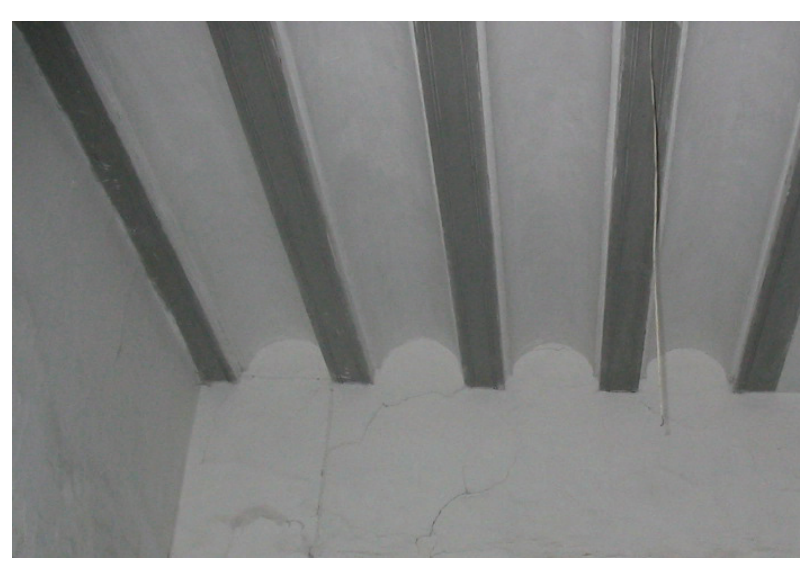

FIGURE 15. Section and picture of jack arch slab.

(a)

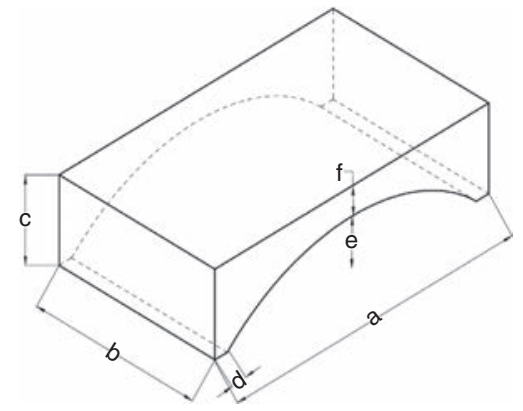

- The dimension of the piece's connections to the wood strips nailed to the existing beams is $2 \mathrm{~cm}(\mathrm{~d})$.

\subsection{Experimental procedure}

In order to carry out an experimental analysis of the infill blocks, three series of six test samples each made of mortars PC-10, PC-20 and PC-30 were prepared. They were then mechanically tested for flexural strength according to the procedure described in the UNE 67-042-88 standard (38) (Figure 17). Although this standard is specific for large-format baked clay ceramic pieces, it was applied here because of the formal similarity between the pieces used in this experiment and those referenced in that regulation, and because there is no existing legislation that corresponds to the pieces developed.

The results from this test are compiled in Table 5. In all cases, the rupture values corresponding to flexural strength are higher than the ones required by current legislation for this type of elements $(\geq 125 \mathrm{Kgf})$. On the other hand, it is observed that the greater the key thickness (f), the higher the value for the load breaking point, making this a crucial parameter for the flexural strength of the piece. Another relevant aspect is the difference between the theoretical value of the key (f) and the real mean value once the mould is removed from around the piece (f-real), with a difference of between 1 and $2 \mathrm{~mm}$.
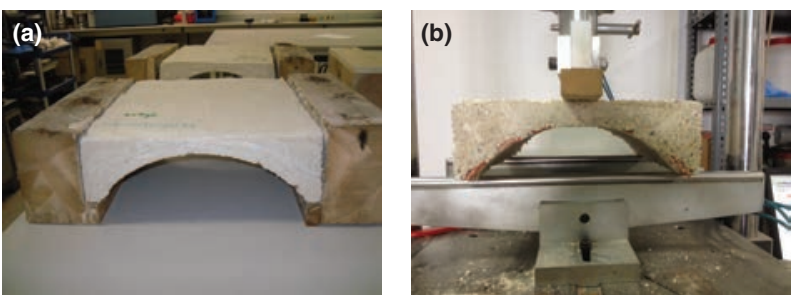

FIgURE 17. a. Pieces fabricated in lab. b. Flexural strength testing on one of the pieces, according to UNE 67-042-88 standard.

(b)

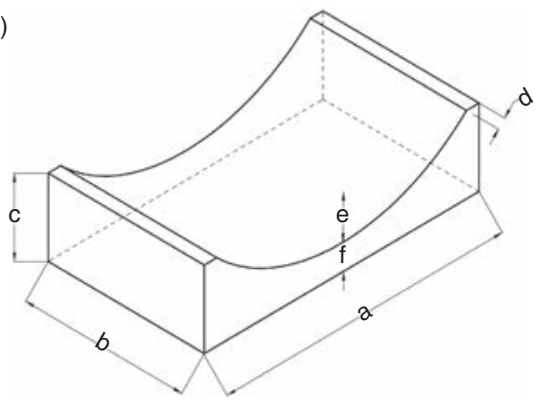

FIGURE 16. Top and bottom view of the filler block. 
Characterisation of recycled ceramic mortars for use in prefabricated beam-filling pieces in structural floors $\bullet 13$

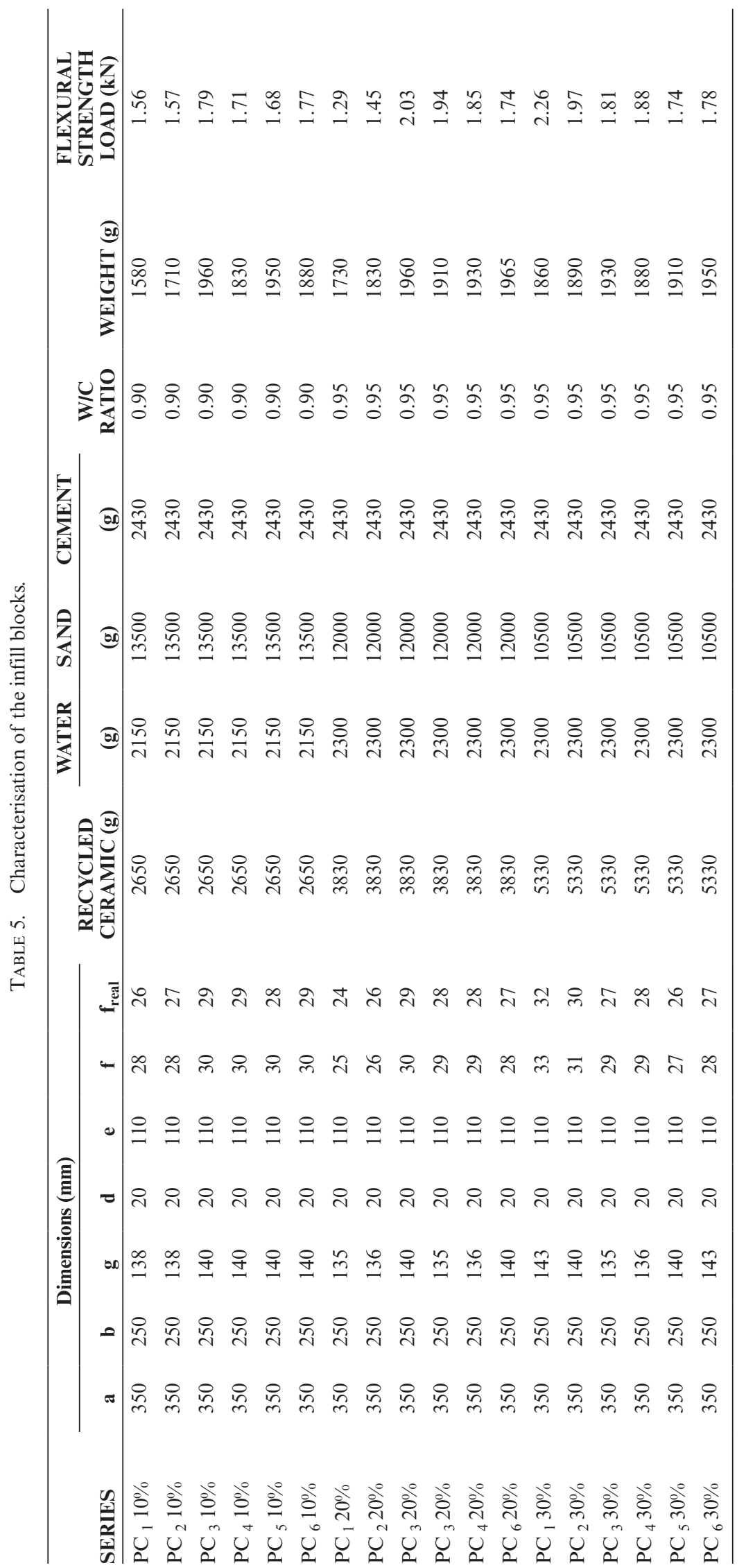


The insertion of this piece into a structural floor was carried out as detailed below. It is important to emphasise that the piece must be supported on wood strips nailed to the existing wood beams or to the new ones (Figure 18):

\subsection{Applying the new piece to a real rehabilitation case: "Casa del Pumarejo", in Seville (Spain).}

\section{Building Description}

To verify the construction and structural viability of the element developed, it was proposed to include the piece in the plans for the rehabilitation of a real building, the Casa del Pumarejo. This is a house with an internal patio of great historical, artistic and patrimonial value located in the old city centre of Seville (Figure 19).

The building is constructed around two arcaded patios that reflect the status of the original occupants: one patio has wooden columns that symbolize the noble space of the house that contains the most interesting decorative elements, and a second patio that is simpler in design, acting as a serving area. These patios influence the spatial organization of all other areas of the building (Figures 20 and 21).

\section{Constructive characterization}

The structural system of the building is based on load-bearing walls of solid clay brick measuring two-and-a-half feet (about $60 \mathrm{~cm}$ ) laid as headers and stretchers. The horizontal structure has a finish that consists of wooden infill beam slabs (Figure 22) resolved by a two-threaded beam fill or vaulted partition walls of solid clay clinker brick with a lowerside finish of plaster cladding containing alcatifa and clay flooring.

\section{Intervention proposal}

The highlighted zone in red in Figure 20 indicates the structural floors that have been analysed in detail for this study.

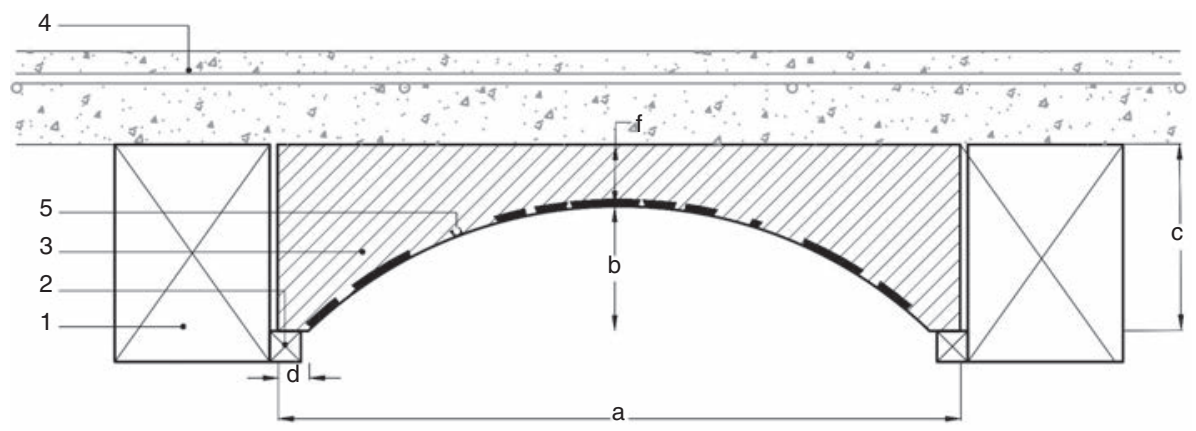

FIGURE 18. Cross-section of the piece supported on timber beams. 1. Timber beams. 2. Strip of Wood. 3. I infill blocks with recycled ceramic mortar. 4. Compression layer. 5. Coating layer of ceramics. (optional).
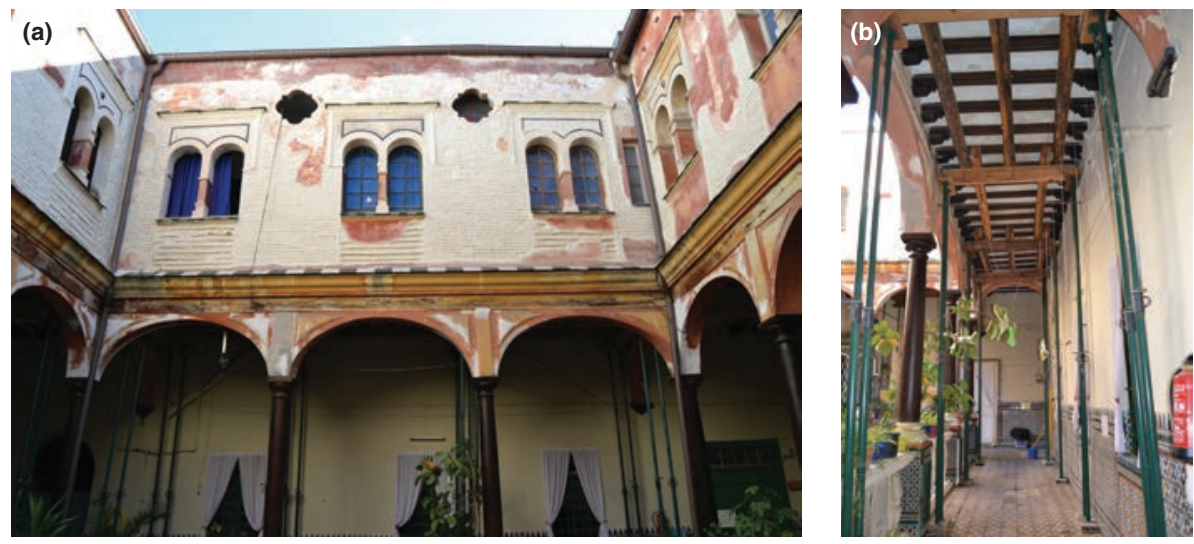

FIGURE 19. Images of the principal arcaded courtyard in Pumarejo's Building. 


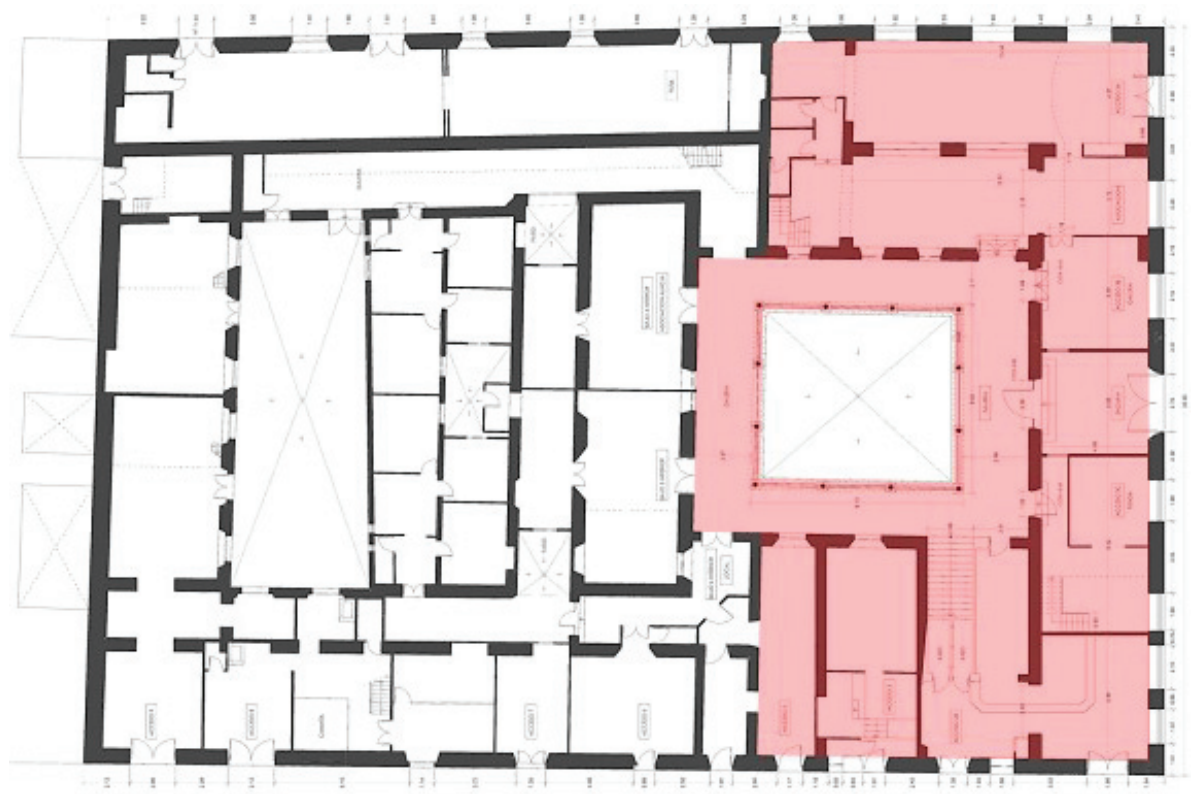

Figure 20. Floor plant of Pumarejo's Building.

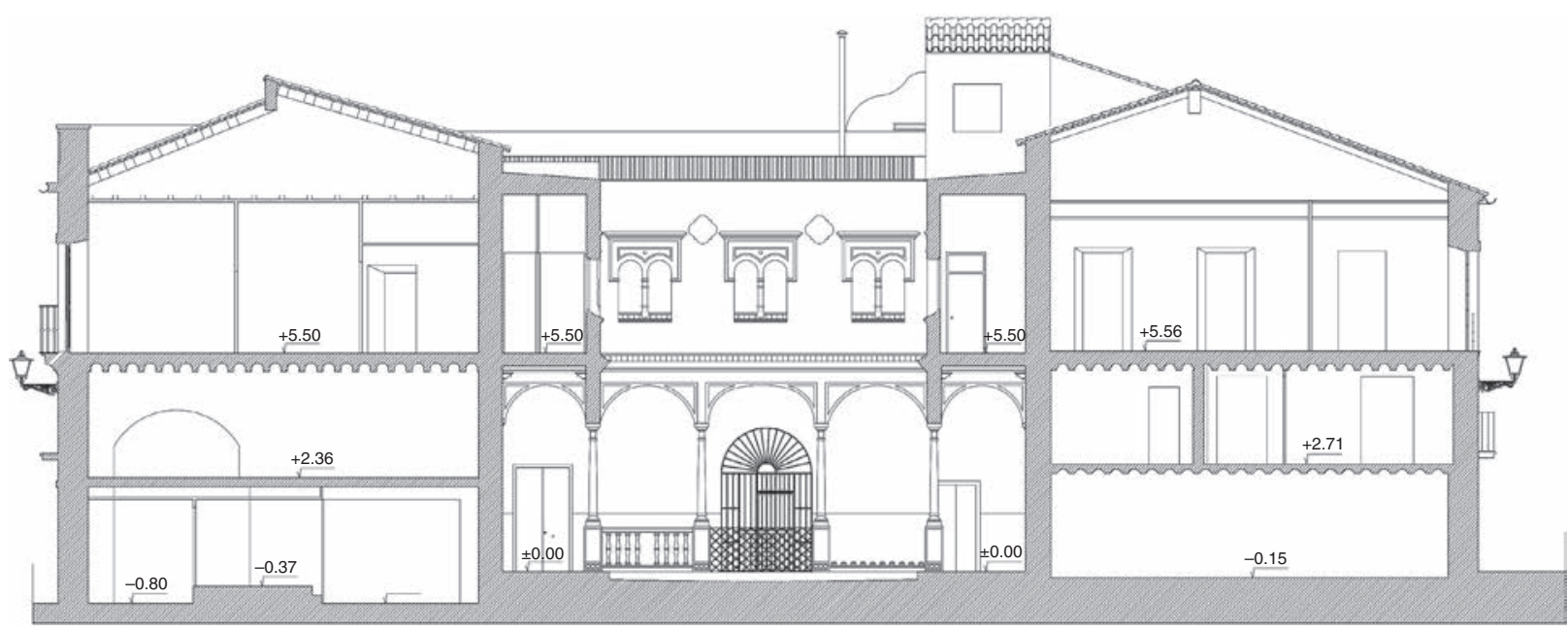

FIgure 21. Cross section of Pumarejo's Building.

(a)

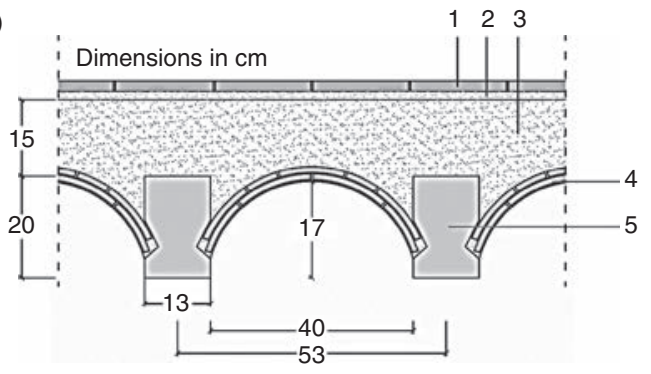

$1.2 \mathrm{~cm}$ ceramic tile floor

2. $2 \mathrm{~cm}$ cement mortar

3. $15 \mathrm{~cm}$ sand filling with ceramic and other waste

4. Beam-filling pieces: ceramic tiles, $1.900 \mathrm{~kg} / \mathrm{m}^{3}$

5. Sawn timber beams, $370 \mathrm{~kg} / \mathrm{m}^{3}$ (b)

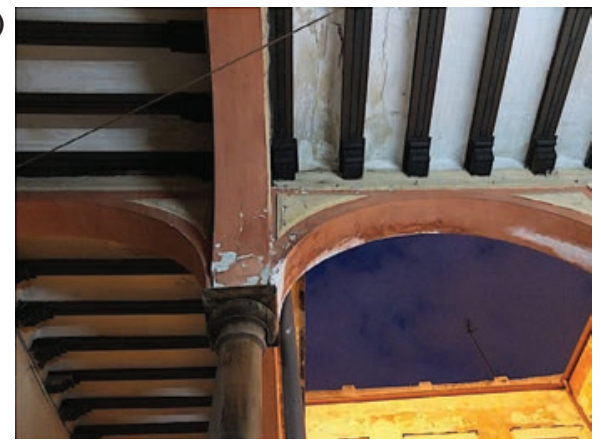

FIgURE 22. (a) Original constructive solution in Pumarejo's Building; (b) Image of the arcaded courtyard with brick jack arch slabs and wood beams 


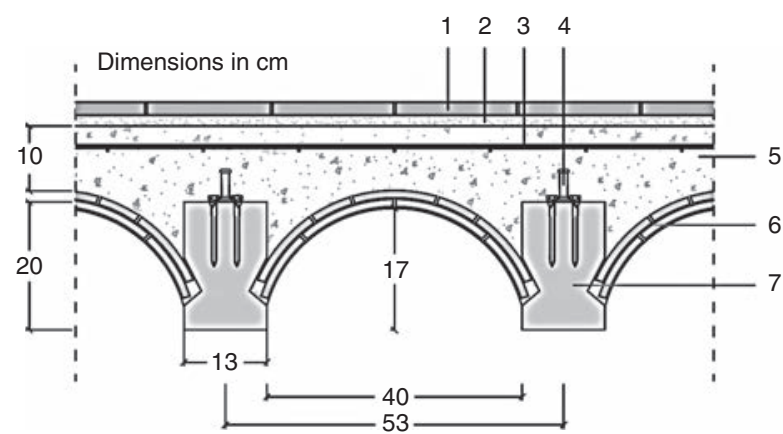

1. $2 \mathrm{~cm}$ ceramic tile floor

2. $2 \mathrm{~cm}$ cement mortar

3. Corrugated steel reinforcement $20 \times 20$ A Ø6-6 B400S

4. Galvanised steel connectors

5. $10 \mathrm{~cm}$ compression layer and lightweight concrete filling, HLE-25/B/10/lla, $1.200 \mathrm{~kg} / \mathrm{m}^{3}$

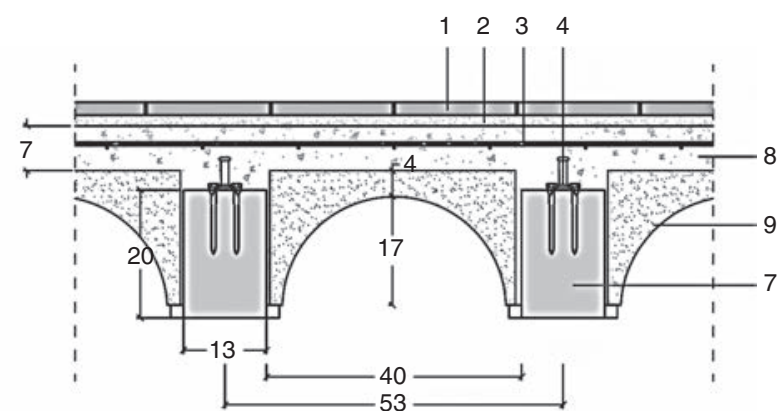

6. Beam-filling pieces: ceramic tiles, $1.800 \mathrm{~kg} / \mathrm{m}^{3}$ 7. Sawn timber beams, $370 \mathrm{~kg} / \mathrm{m}^{3}$

8. $7 \mathrm{~cm}$ compression layer and lightweight concrete filling, HLE-25/B/10/lla, $1.200 \mathrm{~kg} / \mathrm{m}^{3}$

9. Prefabricated beam-filling piece with $30 \%$ of ceramic aggregate

FIGURE 23. Rehabilitation hypothesis: (a) With beam-filling pieces made of ceramic tiles; (b) With prefabricated beam-filling pieces with $30 \%$ of ceramic aggregate.

Two solutions are proposed for the rehabilitation of the slabs that will enable the original wooden beams to be conserved, as well as their dimensions and construction typology. The first option is to construct the brick partition vaults on site (Figure 23a) following the traditional construction procedure. The second option (Figure 23b) is to incorporate the piece developed using recycled clay aggregate.

In both cases, an upper reinforcement is put in place by means of a light reinforced concrete slab (mixed wood-concrete decking). This solution not only maintains the original aesthetic of the slabs on the lower face, it also improves the mechanical behaviour of the beams, achieving greater inertia and resistance, and simultaneously improving its anti-inflammatory characteristics and boosting thermal and/or acoustic insulation, among others. In addition, the use of light concrete considerably reduces the beam weight, a crucial factor in rehabilitation interventions.

\section{Structural study}

The structural assessment of the rehabilitation hypotheses takes into account the procedure in DAV-SE-M (39), in the development of Spanish regulations in CTE-DB-SE-M (38) and consists of a simplification of the calculation specified in Eurocode 5 (40), that refers to cases involving woodconcrete beams in residential buildings. Structural tests were carried out with reference to Limit State Design (LSD) to determine the flexural strength, shear load and shearing force; and to the Limit State
Service specification relating to the slab arrow calculation. Also taken into consideration were the load data in CTE-DB-SE (41). The load-bearing capacity of the structural element for fire resistance was also measured based on the method proposed in Annex E of CTE-DB-SI (42).

The reuse of the original wooden beams $(13 \times 20$ $\mathrm{cm}$ ) was also considered in the calculation, by determining the mechanical behaviour of the beam for two lighting placements, at 3 and $5 \mathrm{~m}$. The results for this calculation are presented in Table 6, which shows that the two hypotheses comply with the legal structural requirements.

In the case of lights at $3 \mathrm{~m}$, the solution using a prefabricated piece complies with minimum mechanical resistance requirements with a compression layer of less than $5 \mathrm{~cm}$. In fact, this thickness is the same for both the solutions proposed as it is the minimum legally permitted value. As a result, both solutions need the same number of connectors per beam ( 8 distributed at intervals of $40 \mathrm{~cm}$ ), for the effective linkage of the wooden material and the concrete.

On the other hand, there is a significant difference in weight between the hypothesised recycled hollow vault compared to the solution consisting of clay floor tiles $\left(2.74 \mathrm{kN} / \mathrm{m}^{2}\right.$ and $3.20 \mathrm{kN} / \mathrm{m}^{2}$, respectively); this improves structural performance with lights at $5 \mathrm{~m}$, reducing the compression layer for the proposed recycled hollow vault to a thickness of $3 \mathrm{~cm}$. However, in this case the number of connectors needed is greater when using the prefabricated piece (33 every $15 \mathrm{~cm}$, compared to 25 each $20 \mathrm{~cm})$. 
TABLE 6. Calculation results of structural behavior of the considered hypothesis (1: With beam-filling pieces made of ceramic tiles; 2: With prefabricated beam-filling pieces with $30 \%$ of ceramic aggregate)

\begin{tabular}{|c|c|c|c|c|c|c|c|c|c|c|}
\hline \multicolumn{11}{|c|}{ STRUCTURAL CALCULATION. ELS / ELU TESTS } \\
\hline \multicolumn{11}{|c|}{ PERMANENT AND SERVICE LOADS } \\
\hline \multicolumn{7}{|c|}{ Elements $\left(\mathrm{kN} / \mathrm{m}^{2}\right)$} & \multicolumn{2}{|c|}{$\begin{array}{c}\text { REHAB. } \\
\text { HYPOTHESIS } 1 \\
\end{array}$} & \multicolumn{2}{|c|}{$\begin{array}{c}\text { REHAB. } \\
\text { HYPOTHESIS } 2 \\
\end{array}$} \\
\hline \multicolumn{7}{|c|}{ Ceramic tile floor, th $=2 \mathrm{~cm}$} & \multicolumn{2}{|c|}{0.40} & \multicolumn{2}{|c|}{0.40} \\
\hline \multicolumn{7}{|c|}{ Cement mortar, th $=2 \mathrm{~cm}$} & \multicolumn{2}{|c|}{0.30} & \multicolumn{2}{|c|}{0.30} \\
\hline \multicolumn{7}{|c|}{ Compression layer and lightweight concrete filling, HLE-25/B/10/IIa, density $1.200 \mathrm{~kg} / \mathrm{m}^{3}$} & \multicolumn{2}{|c|}{1.87} & \multicolumn{2}{|c|}{0.98} \\
\hline \multicolumn{7}{|c|}{ Sawn timber beams $(13 \times 20 \mathrm{~cm})$, separated $53 \mathrm{~cm}$, density $370 \mathrm{~kg} / \mathrm{cm}^{3}$} & \multicolumn{2}{|c|}{0.18} & \multicolumn{2}{|c|}{0.20} \\
\hline \multicolumn{7}{|c|}{ Beam-filling pieces: ceramic tiles, density $1.800 \mathrm{~kg} / \mathrm{m}^{3}$} & \multicolumn{2}{|c|}{0.45} & \multicolumn{2}{|l|}{-} \\
\hline \multicolumn{7}{|c|}{ Prefabricated beam-filling pieces with ceramic aggregates } & \multicolumn{2}{|c|}{-} & \multicolumn{2}{|c|}{0.85} \\
\hline \multicolumn{7}{|l|}{ TOTAL } & \multicolumn{2}{|c|}{3.20} & \multicolumn{2}{|c|}{2.74} \\
\hline \multicolumn{7}{|c|}{ Partition walls } & \multicolumn{2}{|c|}{1.20} & \multicolumn{2}{|c|}{1.20} \\
\hline \multicolumn{7}{|c|}{ Residential zone A1 } & \multicolumn{2}{|c|}{2.00} & \multicolumn{2}{|c|}{2.00} \\
\hline \multicolumn{11}{|c|}{ RESULTS } \\
\hline \multirow[b]{2}{*}{$\begin{array}{l}\text { Rehab. } \\
\text { hypothesis }\end{array}$} & & & & & ELU & & ELS & R-60 & Conne & tors \\
\hline & $\begin{array}{c}\text { Floor } \\
\text { span (m) }\end{array}$ & $\begin{array}{l}\text { Beams } \\
(\mathrm{cm})\end{array}$ & $\begin{array}{l}\text { Concrete } \\
\text { layer }(\mathrm{cm})\end{array}$ & $\begin{array}{c}\text { Flexural } \\
\text { load } \\
\left(\mathrm{N} / \mathrm{mm}^{2}\right)\end{array}$ & $\begin{array}{c}\text { Shear } \\
\text { load } \\
\left(\mathrm{N} / \mathrm{mm}^{2}\right)\end{array}$ & $\begin{array}{l}\text { Shearing } \\
\text { Force } \\
\left(\mathrm{N} / \mathrm{mm}^{2}\right)\end{array}$ & $\begin{array}{l}\text { Displacement } \\
(\mathrm{mm})\end{array}$ & $\begin{array}{c}\text { Reaction } \\
\text { to fire }\end{array}$ & $\begin{array}{l}\text { Distance } \\
\text { (cm) }\end{array}$ & $\begin{array}{c}N^{\circ} \text { per } \\
\text { beam }\end{array}$ \\
\hline 1 & 3.00 & $13 \times 20$ & 5.00 & $22.5>1.6$ & $4.3>0.2$ & $24.2>22.8$ & $1.13<7.5$ & Minimum & 40.00 & 8 \\
\hline 2 & & & & $22.5>1.6$ & $4.3>0.2$ & $24.2>0.2$ & $1.13<7.5$ & demands & 40.00 & 8 \\
\hline 1 & 5.00 & & 10.00 & $22.5>5.2$ & $4.3>0.4$ & $48.4>45.3$ & $9.94<12.5$ & & 20.00 & 25 \\
\hline 2 & & & 7.00 & $22.5>4.7$ & $4.3>0.4$ & $41.5>40.3$ & $9.20<12.5$ & & 15.00 & 33 \\
\hline
\end{tabular}

\section{CONCLUSIONS}

The study carried out can be concluded as following:

- Ceramic material from construction waste or surplus production has proved to be a viable substitute for commercial aggregate in the production of mortars. Its composition, with a high percentage of quartz, means that the mineralogical phases are similar to the ones formed in cement mortar with no added ceramic.

- To guarantee the workability of the mortar with ceramic waste that is equal or above substitution ratios of $30 \%$, it would be necessary to increase water content, with a water/cement ratio as high as 1.05 or, as an alternative, use additives to improve this characteristic in order to comply with current regulations.

- The densities of hardened mortars were successfully reduced by up to $8 \%$ in mixtures with $50 \%$ added ceramic, compared to the reference mortar with no additives. This benefits the manufacture of prefabricated pieces, using these mortars as base material.

- Mortars with a recycled ceramic content of 20 and $30 \%$ have proved to be optimal when tested for water absorption. A reduction of approximately $50 \%$ in water absorption was achieved in the test pieces. No significant improvements in the mixtures with high ceramic ratios were obtained due to the heterogeneity of these mortars.

- Although porosity increases considerably as the percentage of ceramic content rises, the pores are uniformly distributed in mixtures with a ratio equal to or less than $30 \%$ and the samples did not show substantial voids. All this explains the results obtained in the water absorption tests.

- Tests showed a significant increase in compression and flexural strength values in mixtures up to $30 \%(23.58 \mathrm{MPa})$, thereafter declining but with levels that were always above the reference mortar with no ceramic added. 
- This study has demonstrated that mortar with $30 \%$ added recycled ceramic from construction waste is the most appropriate for use in the production of prefabricated pieces, thanks to its outstanding results in physical and mechanical properties.

- A prefabricated piece has been developed to allow the recovery of a type of structural floor made of infill blocks of jack arch slabs and wood beams typical of the $17^{\text {th }}$ to $19^{\text {th }}$ centuries. The solution presented enables the maximum utilization of existing beams, contributing to the sustainability of these rehabilitated horizontal structures. Moreover, the piece developed meets the legal standards of current legislation so it can be legitimately used in construction works.

- The new infill made of mortars with ceramic waste in a proportion of $30 \%$ allows for a reduction of $0.61 \mathrm{kN} / \mathrm{m}^{2}$ compared to the traditional solution usually applied in the rehabilitation of these types of structural floors, and considering a compression layer of $6 \mathrm{~cm}$ thick in both cases.

- The application of the new pieces proposed in an authentic rehabilitation project yields structural improvements that are superior to those offered by traditional solutions since the solution is lighter. The new pieces involve substantial reuse of waste clay, a quicker construction process and minimization of waste generated on site.

\section{ACKNOWLEDGEMENTS}

This research has been supported by the Ministry of Economy and Competitiveness of Spain (reference number BIA2013-43061-R). The author $\mathbf{M}^{\mathrm{a}}$ Jesús Morales-Conde acknowledges the financial support of the V Research Plan of the University of Seville. Pedreño-Rojas, MA (author) wishes to acknowledge the financial support provided by the FPU Program of Spain's Ministry of Education (FPU15/02939). The authors acknowledge the collaboration in this work of the architects Carmen Calama, Carlos Campos and Carlos Girón.

\section{REFERENCES}

1. Instituto Nacional de Estadística. Encuesta sobre la recogida y tratamiento de residuos urbanos y la generación de residuos en los sectores servicios y de la construcción en el año 2011. 2013.

2. Plan de Gestión de Residuos de Construcción y Demolición de la Consejería de Medio Ambiente y Ordenación del Territorio. Comunidad de Madrid (2006-2016).

3. CEDEX, Centro de Estudios y Experimentación de obras Públicas. Ficha técnica Residuos de Construcción y Demolición. 2014

4. Plan Estatal Marco de de Gestión de Residuos 2016-2022 (PEMAR) Secretaria de Estado de Medio ambiente. Ministerio de Agricultura, Alimentación y Medio ambiente. Gobierno de España.
5. EHE. Instrucción Española de Hormigón Estructural EHE-08 (Spanish Code Structural Concrete). Ministerio de Fomento, Madrid; 2008 [Spanish]

6. Hansen, T.C. (2004) RILEM REPORT Recycling of Demolished Concrete and Masonry. E\&FN Spon, Bodmin, UK, (2004); 6

7. Pereira-de-Oliveira, L. A.; Castro-Gomes, J. P.; Santos, P. M. (2015) The potential puzzolanic activity of glass and red-clay ceramic waste as cement mortars components. Constr. Build. Mater. 31, 197-203. https://doi. org/10.1016/j.conbuildmat.2011.12.110

8. Medina, C.; Juan, A.; Frías, M.; Sánchez de Rojas, M. I.; Morán, J. M.; Guerra, M. I. (2011) Characterization of concrete made with recycled aggregate from ceramic sanitary ware. Mater. Construcc. 61 [304], 533-546. https://doi. org/10.3989/mc.2011.59710

9. Medina, C.; Sánchez de Rojas, M. I.; Frías, M. (2012) Reuse of sanitary ceramic wastes as coarse aggregate in eco-efficient concretes. Cem. Concr. Compos. 34 [1], 48-54. https://doi.org/10.1016/j.cemconcomp.2011.08.015

10. Medina, C.; Frías, M.; Sanchez de Rojas, M. I. (2012) Microstructure and properties of recycled concretes using ceramic sanitary ware industry waste as coarse aggregate. Constr. Build. Mater. 31, 112-118. https://doi. org/10.1016/j.conbuildmat.2011.12.075

11. Medina, C.; Sanchez de Rojas, M. I.; Frías, M. (2013) Properties of recycled ceramic aggregate concretes: water resistance. Cem. Concr. Compos. 40, 21-29. https://doi. org/10.1016/j.cemconcomp.2013.04.005

12. Medina, C.; Sanchez de Rojas, M. I.; Thomas, C.; Polanco, J. A.; Frías, M. (2016) Durability of recycled concrete made with recycled ceramic sanitary ware aggregate. Interindicator relationships. Constr. Build. Mater. 105, 480-486. https://doi.org/10.1016/j.conbuildmat.2015.12.176

13. Corinaldesi, V. (2012) Environmentally-friendly bedding mortars forrepair of historical buildings. Constr. Build. Mater. 35, 778-784. https://doi.org/10.1016/j. conbuildmat.2012.04.131

14. Matias, G.; Faria, P.; Torres, I. (2014) Lime mortars with ceramic wastes: characterization of components and their influence on the mechanical behaviour. Constr. Build. Mater. 73, 523-534. https://doi.org/10.1016/j. conbuildmat.2014.09.108

15. Ledesma, E. F.; Jiménez, J. R.; Ayuso, J.; Fernández, J. M.; de Brito, J. (2015) Maximum feasible use of recycled sand from construction and demolition waste for eco-mortar production-Part-I: ceramic masonry waste. J Clean. Prod. 87, 692-706. https://doi.org/10.1016/j.jclepro.2014.10.084

16. Jiménez, J. R.; Ayuso, J.; López, M.; Fernández, J. M.; De Brito, J. (2013) Use of fine recycled aggregates from ceramic waste in masonry mortar manufacturing. Constr. Build. Mater. 40, 679-690. https://doi.org/10.1016/j. conbuildmat.2012.11.036

17. Silva, J.; De Brito, J.; Veiga, R. (2010) Recycled red-clay ceramic construction and demolition waste for mortars production. J. Mater. Civil Eng. 22 [3], 236-244. https:// doi.org/10.1061/(ASCE)0899-1561(2010)22:3(236)

18. Farinha, C.; de Brito, J.; Veiga, R. (2015) Incorporation of fine sanitary ware aggregates in coating mortars. Constr. Build. Mater. 83, 194-206. https://doi.org/10.1016/j. conbuildmat.2015.03.028

19. Katzer, J. (2013) Strength performance comparison of mortars made with waste fine aggregate and ceramic fume. Constr. Build. Mater. 2013; 47:1-6. https://doi. org/10.1016/j.conbuildmat.2013.04.039

20. Schackow, A.; Stringari, D.; Senff, L.; Correia, S. L.; Segadães, A. M. (2015) Influence of firedclay brick waste addition son the durability of mortars. Cem. Concr. Compos. 62, 82-89. https://doi.org/10.1016/j. cemconcomp.2015.04.019

21. Silva, J.; de Brito, J.; Veiga, R. (2009) Incorporation of fine ceramics in mortars. Constr. Build. Mater. 23 [1], 556-564. https://doi.org/10.1016/j.conbuildmat.2007.10.014

22. Poon, C. S.; Kou, S. C.; Lam, L. (2002) Use of recycled aggregates in molded concrete bricks and blocks. Constr. 
Build. Mater. 16 [5], 281-289. https://doi.org/10.1016/ S0950-0618(02)00019-3

23. Soutsos, M. N.; Tang, K.; Millard, S. G. (2012) The use of recycled demolition aggregate in precast concrete products-Phase III: Concrete pavement flags. Constr. Build. Mater. 36, 674-680. https://doi.org/10.1016/j. conbuildmat.2012.06.045

24. Poon, C. S.; Chan, D. (2006) Paving blocks made with recycled concrete aggregate and crushed clay brick. Constr. Build. Mater. 20 [8], 569-577. https://doi.org/10.1016/j. conbuildmat.2005.01.044

25. Jankovic, K.; Nikolic, D.; Bojovic, D. (2012) Concrete paving blocks and flag made with crushed brick as aggregate. Constr. Build. Mater. 28 [1], 659-663. https://doi. org/10.1016/j.conbuildmat.2011.10.036

26. Sadek, D. M.; El Nouhy, H. A. (2014) Properties of paving unit sin corporating crushed ceramic. HBRC Journal. 10 [2], 198-205. https://doi.org/10.1016/j.hbrcj.2013. 11.006

27. Penteado, C. S. G.; de Carvalho, E. V.; Lintz, R. C. C. (2016) Reusing ceramic tile polishing waste in paving block manufacturing. J. Clean. Prod. 112, 514-520. https://doi. org/10.1016/j.jclepro.2015.06.142

28. Agrela, F.; Barbudo, A.; Ramírez, A.; Ayuso, J.; Carvajal, M. D.; Jiménez, J. R. (2012) Construction of road section using mixed recycled aggregates treated with cement in Malaga, Spain. Resour. Conserv. Recy. 58, 98-106. https:// doi.org/10.1016/j.resconrec.2011.11.003

29. España. Real Decreto 256/2016. Boletín oficial del Estado, 25 de Junio de 2016, n 153, 45755 - 45824. Available at: https://www.boe.es/diario_boe/txt.php?id= BOE-A-2016-6167\#analisis

30. UNE-EN 933-1:2012. European standard. Tests for geometrical properties of aggregates - Part 1: Determination of particle size distribution - Sieving method.
31. UNE-EN 1015-11:2000. European standard. Methods of test for mortar for masonry - Part 11: Determination of flexural and compressive strength of hardened mortar.

32. UNE-EN 1015-6:1999/A1:2007. European standard. Methods of test for mortar for masonry - Part 6: Determination of bulk density of fresh mortar

33. UNE-EN 1015-3:2000. European standard. Methods of test for mortar for masonry - Part 3: Determination of consistence of fresh mortar (by flow table).

34. UNE-EN 1015-10:2000. European standard. Methods of test for mortar for masonry - Part 10: Determination of dry bulk density of hardened mortar.

35. UNE-EN 1015-18:2003. European standard. Methods of test for mortar masonry - Part 18: Determination of water absorption coefficient due to capillary action of hardened mortar.

36. UNE-EN 12390-13:2014. European standard. Testing hardened concrete - Part 13: Determination of secant modulus of elasticity in compression.

37. Rubio-de-Hita, P.; Pérez-Gálvez, F.; Morales-Conde, M. J.; Rodríguez-Liñán, C. (2016) Procedimiento para la fabricación de morteros con residuos cerámicos y su aplicación en una pieza de entrevigado para forjados con vigas de madera. P201601008.

38. UNE-EN 67042:1988. European standard. Big ceramic pieces of burned clay. Determination of the modulus of rupture.

39. CTE-DB-SE-M: 2006. Código Técnico de la Edificación. Documento Básico de Seguridad Estructural: Madera.

40. Eurocode 5 (2003). Eurocode 5-Design of timber structures-Part 1-1: General rules and rules for buildings.

41. CTE-DB-SE: 2006. Código Técnico de la Edificación. Documento Básico de Seguridad Estructural.

42. CTE-DB-SI: 2006. Código Técnico de la Edificación. Documento Básico de Seguridad ante Incendio. 